\title{
Fine-scale sea-ice modelling of the Storfjorden polynya, Svalbard
}

\author{
Lars H. SMEDSRUD, ${ }^{1}$ W. Paul BUDGELL, ${ }^{1,2}$ Alastair D. JENKINS, ${ }^{1}$ \\ Bjørn ÅDLANDSVIK ${ }^{1,2}$ \\ ${ }^{1}$ Bjerknes Centre for Climate Research, University of Bergen, Allegaten 70, NO-5007 Bergen, Norway \\ E-mail: larsh@gfi.uib.no \\ ${ }^{2}$ Institute of Marine Research, PO Box 1870 Nordnes, NO-5817 Bergen, Norway
}

\begin{abstract}
A polynya appears regularly in Storfjorden on the east side of the Svalbard archipelago. It is mainly forced by offshore winds and contributes around $10 \%$ of the brine water produced on Arctic shelves. We have applied a regional ocean model (ROMS), including a sea-ice model, on a fine grid $(2 \mathrm{~km})$ to simulate a full year of sea-ice growth and decay starting on 1 August 1999. This allows us to reproduce some key processes of the polynya opening and closing events during January-April 2000. The polynya remains open as long as the offshore winds exist, and reaches a width along the direction of the wind of $10-20 \mathrm{~km}$. We suggest using a mean sea-ice thickness of $<0.3 \mathrm{~m}$ as the polynya criterion, as our simulations show varying strength in the horizontal gradients in sea-ice concentration and thickness. Results show a general freeze-up during December and January, with a mean polynya area during February-April within the fjord of 33 by $50 \mathrm{~km}$, being $13 \%$ of the total fjord area. Some model results including sea-ice cover and drift speed can be partially validated using satellite imagery and field data, but in general are new measurements from the polynya interior needed to further improve the modelling of solid- and grease-ice processes.
\end{abstract}

\section{INTRODUCTION}

The most efficient ice production in the Arctic and Antarctic is found in coastal regions, where dry cold winds force the sea-ice cover offshore and create an area of ice-free ocean called a polynya. Such polynyas are classified as latent-heat polynyas, as the latent heat from sea-ice formation warms the air above, and may also be termed coastal or winddriven polynyas (Morales Maqueda and others, 2004). The distance the polynya extends from the coastline is governed by the balance between the export of ice and the production of ice within. Polynyas play an important role for the underlying ocean, by increasing the shelf-water density through cooling and brine rejection, and sequestering oxygen and $\mathrm{CO}_{2}$ through the air-sea interface.

The first ice that forms in a polynya is composed of loose ice crystals called frazil ice. Depending on the level of turbulence, frazil ice will be mixed downwards, to form a surface layer of grease ice of varying thickness. Grease ice is therefore a mixture of frazil crystals and sea water, and recent field observations (Smedsrud and Skogseth, 2006) indicate that the grease-ice bulk salinity gradually decreases from that of the surface water ( $\sim 35$ psu (practical salinity units)) to around 25 psu. When the grease ice congeals into solid ice, or nilas, salinity has decreased further to around 13 psu.

The densest brine-enriched shelf water transformed by the ice-growth process in the coastal polynyas along the Arctic continental shelf can reach the deep Arctic Ocean. The less dense brine-enriched shelf water supplies the cold Arctic halocline by settling between the cold, fresh Arctic surface water and the warm, saline Atlantic layer (Winsor and Björk, 2000). In this way, Arctic coastal polynyas help inhibiting upward mixing of warm Atlantic water, and thus contribute to preventing the Arctic sea-ice cover from melting. According to Cavalieri and Martin (1994), Arctic coastal polynyas generate about $0.7-1.2 \mathrm{~Sv}\left(1 \mathrm{~Sv} \equiv 10^{6} \mathrm{~m}^{3} \mathrm{~s}^{-1}\right)$ of dense water, while Winsor and Björk (2000) estimated the flux out from the shelves to be $0.2 \mathrm{~Sv}$.
The Storfjorden polynya in Svalbard produced close to $0.03 \mathrm{~Sv}$ of brine-enriched shelf water in the winters 19982001 (Skogseth and others, 2004), being 3-15\% of the Arctic total. The seasonal cycle in temperature is strong, as Storfjorden has direct inflow of North Atlantic water with temperature above $3^{\circ} \mathrm{C}$ and salinity above 35 psu; however most of the observations during winter are at the freezing point (Skogseth and others, 2004).

Our knowledge of polynyas has increased over the last few years, but in situ observations remain scarce and are usually limited to remote sensing, moored instruments, and interpolation from nearby meteorological stations. Pease (1987) defined a robust and straightforward analytical model of a wind-driven polynya, and a comparison between a more advanced analytical model and a fine-scale $(2 \mathrm{~km}$ resolution) thermodynamic sea-ice model was performed by Björnsson and others (2001) using an idealized coastline. Recent and earlier polynya studies were reviewed by Morales Maqueda and others (2004).

We present here model results for sea-ice growth and polynya events during winter 1999/2000 in Storfjorden (Fig. 1). We discuss how to define a polynya in terms of seaice concentration and thickness, and validate the results using field data, satellite images and analytical modelling. Such detailed polynya studies are rare, although an exception is that of the Mertz Glacier Polynya, East Antarctica, (Marsland and others, 2004) which applied a resolution up to $12 \mathrm{~km}$. Oceanographic results and validation for our calculations are in progress and will be reported elsewhere, and polynya climatology experiments will be carried out in the future.

\section{METHODS}

This study uses the Rutgers/UCLA Regional Ocean Model System (ROMS) (Shchepetkin and McWilliams, 2005). The ROMS model is a three-dimensional baroclinic ocean model. 


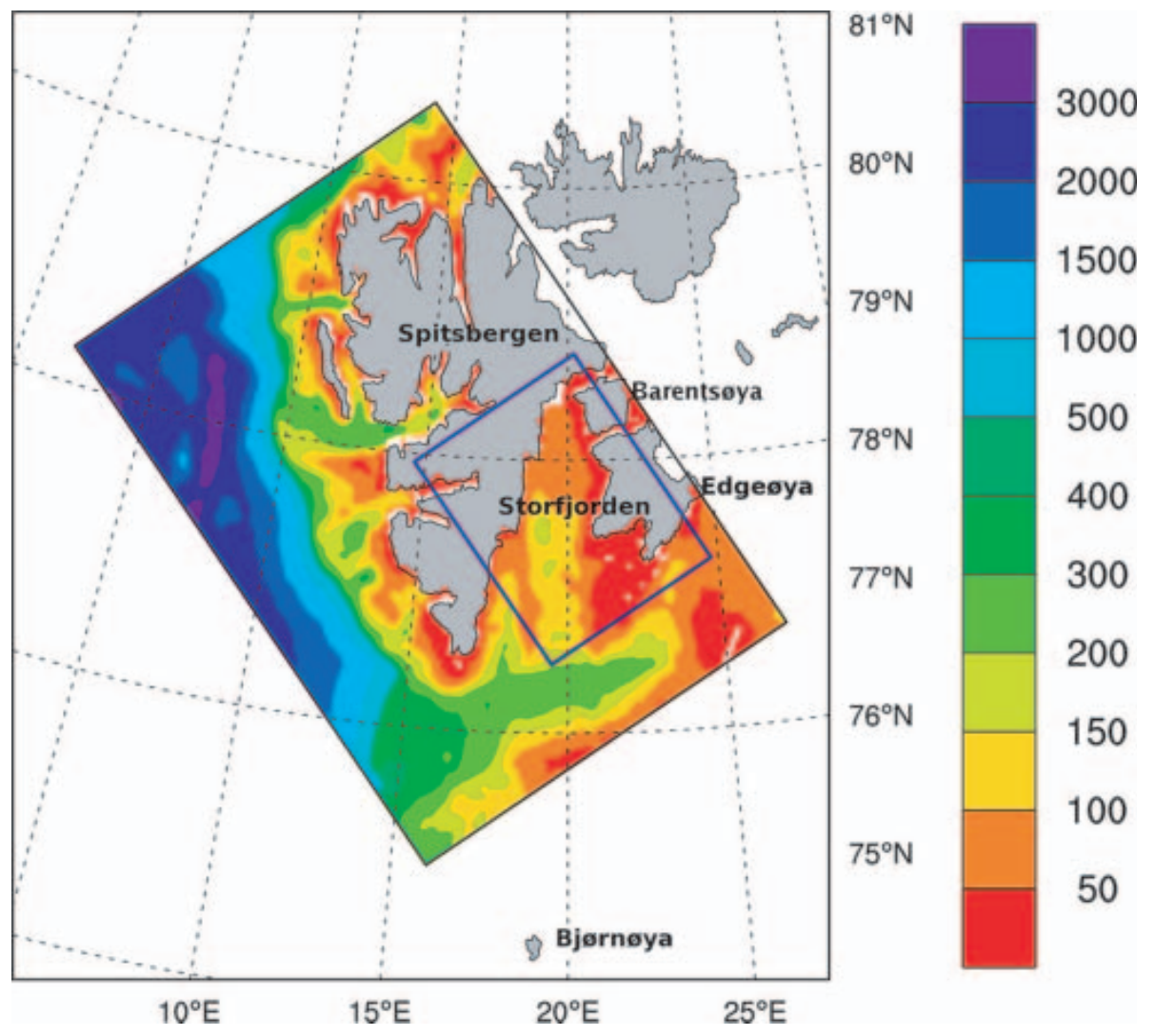

Fig. 1. Svalbard archipelago and Storfjorden. The filled area shows the bathymetry of the $2 \mathrm{~km}$ resolution ROMS model domain $(180 \times 260$ gridcells), and the smaller frame indicates the extent of the model results presented here.

It employs terrain-following coordinates in the vertical, and general orthogonal curvilinear coordinates horizontally.

The ROMS model has been used in a three-stage one-way nesting configuration. A basin-scale model for the North Atlantic and Arctic Oceans has been used to give initial and boundary conditions for an intermediate-scale model (average grid size $9.3 \mathrm{~km}$ ) covering the Barents and Kara Seas (Budgell, 2005). This intermediate model has been used to provide initial and boundary conditions for the $2 \times 2 \mathrm{~km}$ model for the Storfjorden area presented here. The nesting steps are performed using the flow relaxation scheme (Engedahl, 1995) as an open boundary scheme for both ocean and ice variables. Tides were not included in the present simulation.

The ROMS model is highly flexible and includes a variety of different turbulence closure sub-models. The generic length scale (GLS) scheme (Warner and others, 2005) was used for subgrid-scale mixing of mass and momentum, with the two-equation k-kl model parameters. The k-kl model is a modified form of the Mellor-Yamada 2.5 closure (Mellor and Yamada, 1982). This scheme was found to perform well in the Budgell (2005) study of ice-ocean interaction processes in the Barents Sea, where the basic ROMS model was complemented by a fully coupled dynamic and thermodynamic sea-ice sub-model. The main prognostic variables here are ice concentration and ice thickness. The ice dynamics is elastic-viscous-plastic (Hunke and Dukowicz, 1997; Hunke, 2001). The thermodynamic calculations employ two ice layers and one snow layer following Mellor and Kantha (1989) and Häkkinen and Mellor (1992).

The fine-scale, $2 \mathrm{~km}$ resolution, domain is shown in Figure 1. It is obtained by a rotated polar stereographic map projection. The bottom topography is interpolated from the 2' global dataset of the US National Geophysical Data Center (2001 version; http://www.ngdc.noaa.gov/mgg/fliers/ 06mgg01.html). The land mask is modified manually to fit the global self-consistent, hierarchical, high-resolution shoreline database (GSHHS) coastline (Wessel and Smith, 1996). The topography was smoothed by a Shapiro filter. In the vertical, 30 levels are used, with a finer resolution near the surface and the bottom. This is the first time that the model system, including the sea-ice model, has been applied at such a fine grid resolution.

Daily values of wind stress, sensitive- and latent-heat fluxes, solar and longwave radiation, and precipitation were obtained from the US National Centers for Environmental Prediction (NCEP)/US National Center for Atmospheric Research (NCAR) re-analysis (Kalnay and others, 1996) to drive the model for a 1 year cycle of ice growth and decay in Storfjorden, starting from ice-free conditions in August 1999, through July 2000. To run 1 year took 10.1 hours wall-clock time on 16 processors on an IBM e1350 Linux cluster using $\mathrm{SCl}$ high-speed interconnect. The model parallelizes very efficiently for both the ice and ocean components using the Message Passing Interface scheme on clusters and other distributed-memory architectures. The model is split-mode explicit and the time-step was $200 \mathrm{~s}$, with an external mode time-step of $5 \mathrm{~s}$.

\section{RESULTS}

Our simulations show that the first patches of sea ice form at the northern end of Storfjorden at the end of October 1999, but sea surface temperatures are still above $1.0^{\circ} \mathrm{C}$ in the 

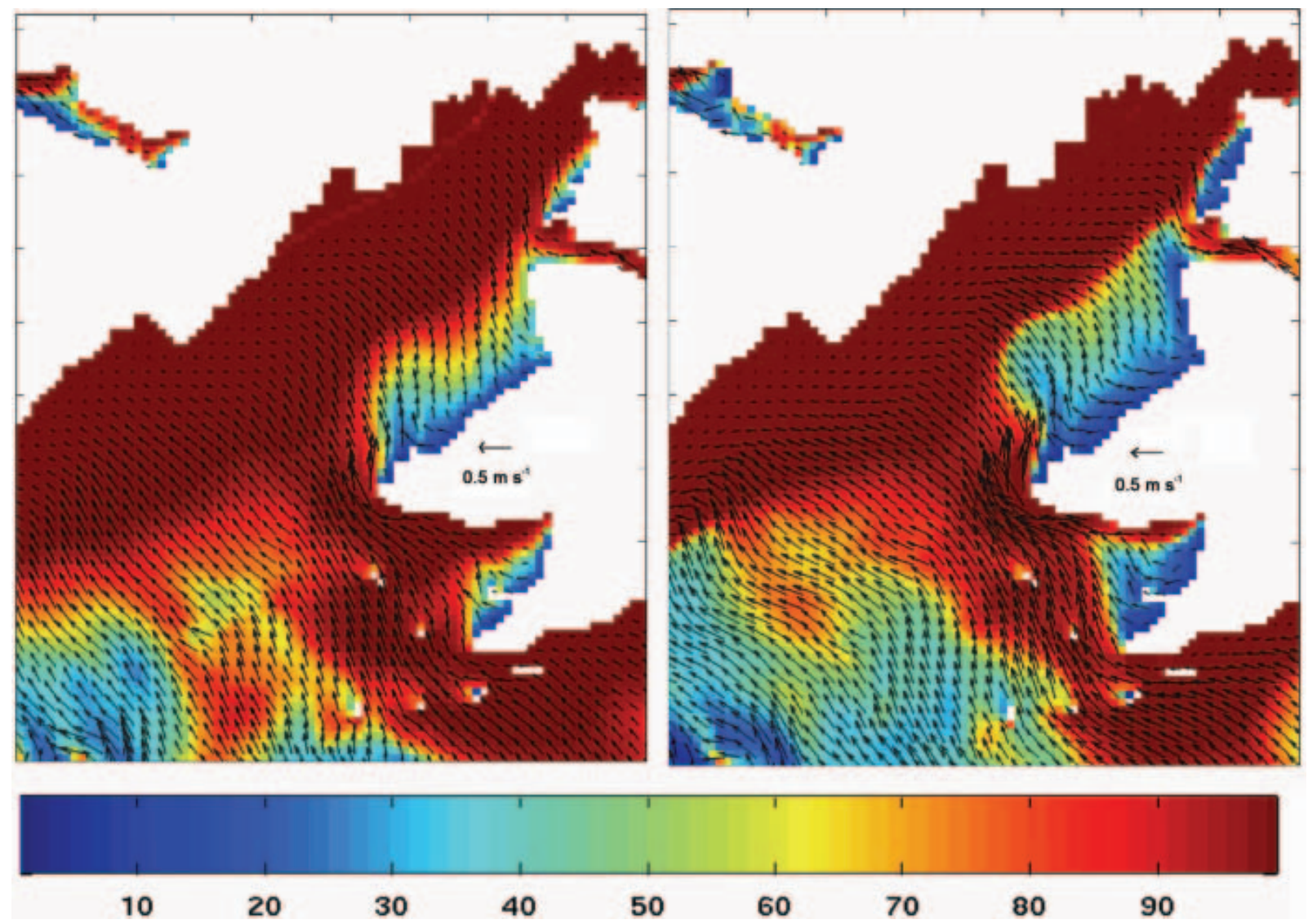

Fig. 2. Sea-ice concentration (\%) and velocity ( $\mathrm{m} \mathrm{s}-1$ ) calculated by the ROMS model for 6 February (left) and 7 February (right) 2000 . This is the start of the major polynya event in Storfjorden during the winter of 1999/2000. Plotted values are daily means (see Fig. 1 for location).

southern parts. In mid-November, bands of ice also form along Edgeøya, and sea surface temperatures have fallen below $0^{\circ} \mathrm{C}$ everywhere in the fjord. It is not until midDecember that most of Storfjorden becomes ice-covered, and the fjord has a mean ice concentration around $70 \%$.

During the winter months, the sea-ice concentration in Storfjorden changes quite rapidly in response to wind forcing. This is illustrated in Figure 2, where the sea-ice velocity and concentration is shown on 6 and 7 February 2000. The polynya on 6 February is clearly growing due to advection of sea ice away from Edgeøya. During most of February and until mid-March it remains open, but varies in size. The periods with the largest open-water areas are 6-9 and 25-27 February and 22-24 March.

Polynya closing events take place at certain times throughout the winter. Maximum sea-ice concentration occurs on 23 February and 18 March (not shown), when the entire fjord has an ice concentration above $90 \%$. Some shorter polynya events also occur during April. During May the northern parts of Storfjorden become ice-free, and the remaining ice melts during June.

There is often westward advection of sea ice south of Edgeøya. This ice is advected into the model domain from the Barents Sea, with velocities in the $0.3-0.5 \mathrm{~m} \mathrm{~s}^{-1}$ range (Fig. 2). This ice accumulates partly on the western side of Storfjorden, and contributes to high sea-ice concentrations there. Some sea ice also flows around the southern tip of Spitsbergen (Fig. 1) and melts in the warmer surface waters there.

The polynya extent cannot be estimated solely by sea-ice concentration. Figure 3 shows the sea-ice thickness from the polynya event on 6 February 2000. The main feature seen is the band of thicker ice along the western side of Storfjorden. This ice persists through the winter and may be classified as 'fast ice', i.e. ice that is attached to land all through the winter. It reaches a thickness of up to $3-4 \mathrm{~m}$ in places.

When comparing the ice concentration and thickness (Figs 2 (left) and 3) in the polynya area, it is clear that the area with ice thickness below $0.2 \mathrm{~m}$ also has an ice concentration below $60 \%$. An area with $40-60 \%$ ice concentration may be termed open pack ice (WMO, 1970), but it is clearly a part of the polynya. Only the inner strip towards the shore, about $5-6 \mathrm{~km}$ wide, can be termed open water (ice concentration $<10 \%$ ).

Further away from the polynya off Edgeøya and westward into Storfjorden, both the ice concentration and thickness increase. The transition between the open water and the fast ice is gradual, and we discuss the polynya area, or width, as compared to earlier work, in section 4.

Heat fluxes are daily means prescribed from the NCEP forcing, and typically cool the surface at a rate of 150 $250 \mathrm{~W} \mathrm{~m}^{-2}$ in areas where NCEP has $\sim 50 \%$ sea-ice concentration during January-February. Corrections were performed on the fluxes in cases where surface temperature and ice concentration differed between the NCEP and our ROMS results (Budgell, 2005). Incoming solar radiation is $<5 \mathrm{~W} \mathrm{~m}^{-2}$ in February, but increases to $60 \mathrm{~W} \mathrm{~m}^{-2}$ through March and thus lowers the total heat flux accordingly. The longwave radiation does not depend significantly on ice concentration and is close to $50 \mathrm{~W} \mathrm{~m}^{-2}$, but the sensible heat flux is around $100 \mathrm{~W} \mathrm{~m}^{-2}$ in areas with $50 \%$ sea-ice concentration, and decreases to negative values, i.e. the 

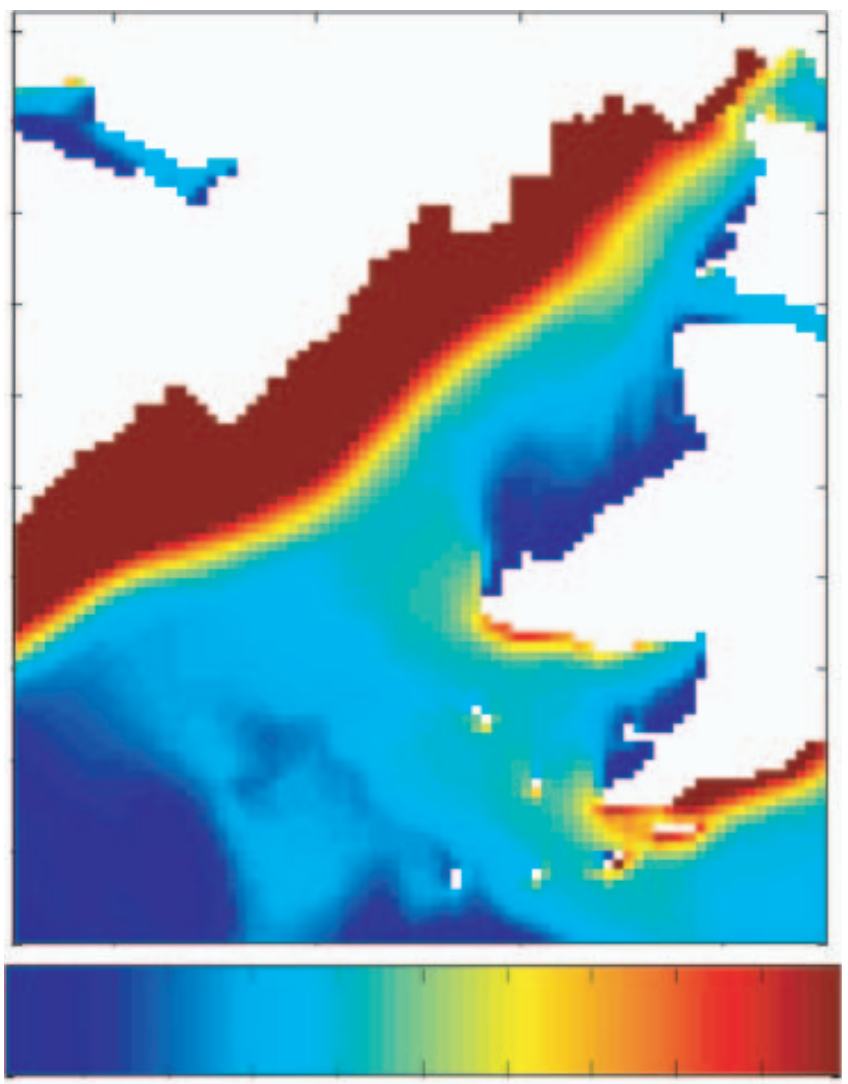

0.2 0.4 0.6 0.8

Fig. 3. Ice thickness $(m)$ calculated by the ROMS model for 6 February during the main polynya event in Storfjorden in the winter of 1999/2000. Plotted values are daily means (see Fig. 1 for location).

air warming the ice, close to $100 \%$ concentration. Latentheat flux also depends on ice concentration, and decreases from around $50 \mathrm{~W} \mathrm{~m}^{-2}$ at $50 \%$ sea-ice concentration to zero flux at $100 \%$ concentration.

Sea-ice drift velocities inside the polynya are typically in the range $0.05-0.3 \mathrm{~m} \mathrm{~s}^{-1}$ (Fig. 2). The ice drift is forced by a daily mean surface stress of close to $0.3 \mathrm{~N} \mathrm{~m}^{-2}$, corresponding to surface winds of $12-15 \mathrm{~m} \mathrm{~s}^{-1}$, depending on the surface drag. The wind direction was directly offshore on 6 and 7 February 2000, i.e. from the east. Polynya closing events are forced by winds which have a strong southerly component. This forces sea ice to drift northwards and pile up against the coast until internal ice forces become equal to the wind drag.

\section{DISCUSSION}

Special Sensor Microwave/Imager (SSM/I) data for the region show that freezing started on 10 November 1999 and ended on 15 May 2000 (D.J. Cavalieri and others, http://nsidc.org/ data/nsidc-0002.html). The resolution of the SSM/I data is $25 \mathrm{~km}$, so the sensor can only validate mean ice cover over such an area. The early smaller patches of ice freezing calculated by the model in October and early November 1999 can therefore not be validated. On 10 November, ROMS calculates an area of $50 \mathrm{~km}$ by $20 \mathrm{~km}$ of $0.05-0.07 \mathrm{~m}$ ice thickness with $20 \%$ sea-ice concentration. This compares well with the SSM/I data, and adds extra detail that
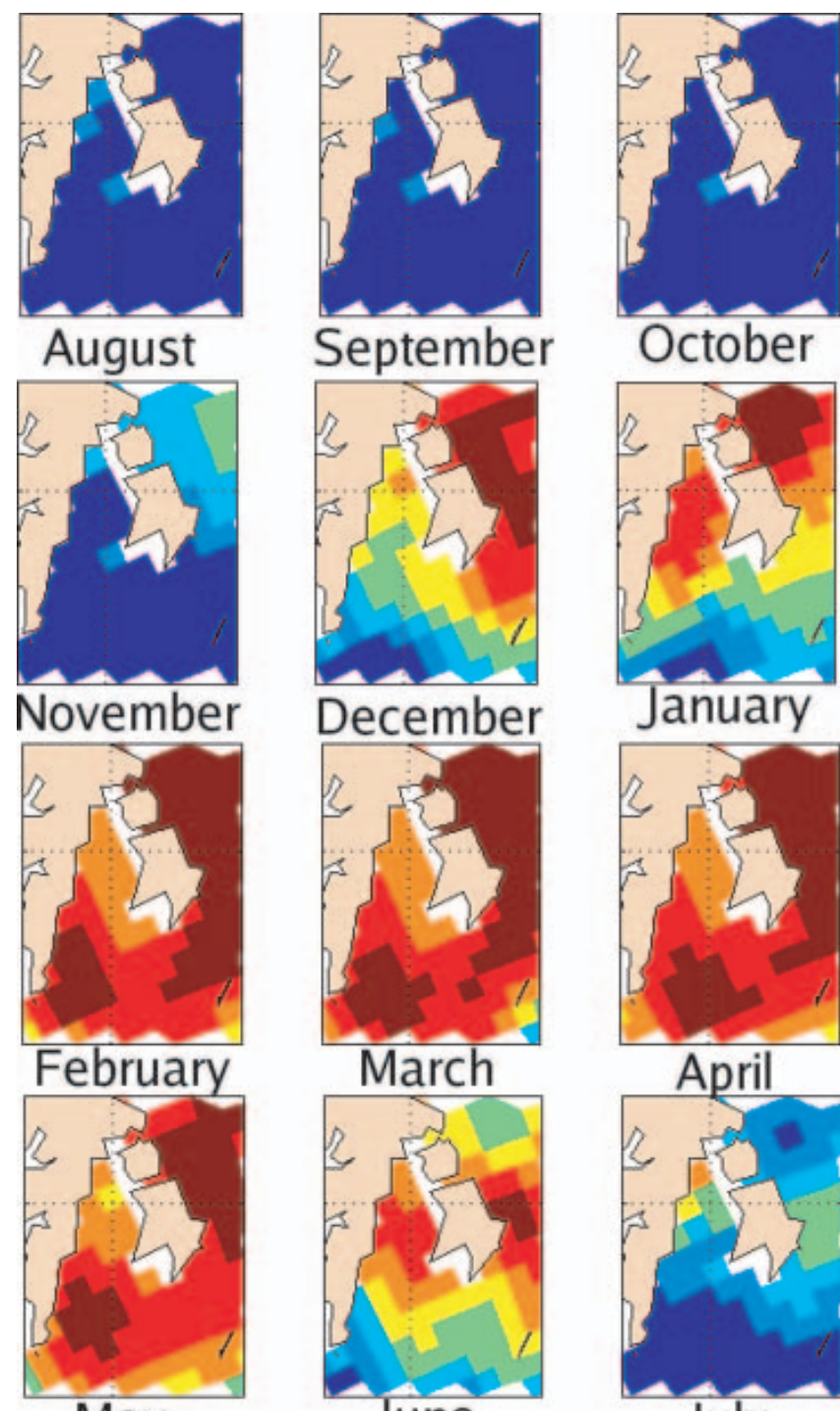

March
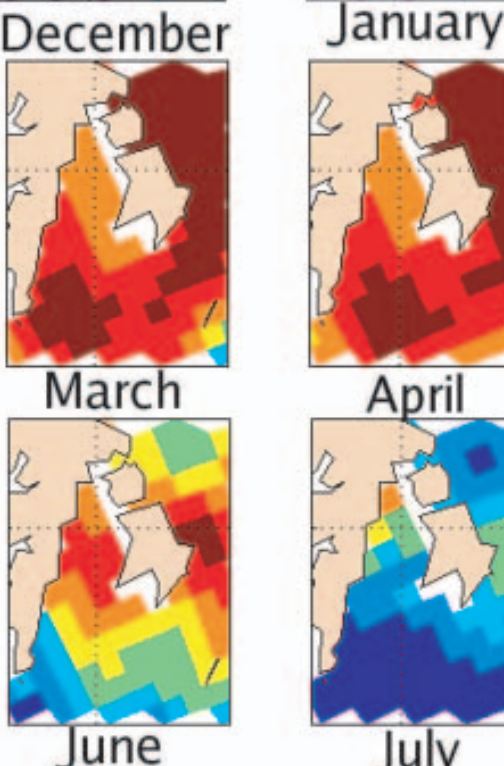

May

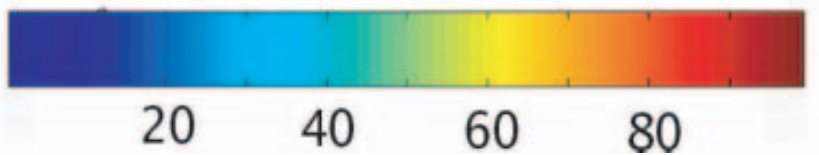

Fig. 4. Monthly mean sea-ice concentration (\%) during 1999/2000 from Defense Satellite Meteorological Program (DMSP) SSM/I passive microwave data in the Storfjorden area.

seems reasonable. ROMS further calculates a gradual freezeup during November-January when the ice cover has reached $0.5 \mathrm{~m}$ thickness. The monthly mean SSM/I sea-ice concentration shown in Figure 4 is $50-60 \%$ during December, and $70-80 \%$ throughout March. There is otherwise little detail to validate our results, apart from an indication of lower sea-ice concentration towards the eastern shores of Storfjorden during the period February-May. Dokken and others (2002) also found that SSM/I data had limited value when estimating polynya size in the Arctic, and recommended modelling based on synthetic aperture radar (SAR) images (with a $25 \mathrm{~m}$ resolution) as the best detection method.

The area of fast ice in Storfjorden is reproduced quite well by the model, compared with the available SAR images (Skogseth and others, 2004). The thicker layer towards the western shore is visible in Figure 2, and stays in the same 
position throughout the winter. The model has no mechanism for attaching sea ice to the coast, so this permanent thick ice cover must be produced by the surface winds.

The overall sea-ice concentration outside Storfjorden to the south is clearly underestimated in our model. Figure 4 shows concentrations of above $80 \%$ between $76^{\circ} \mathrm{N}$ and $77^{\circ} \mathrm{N}$ in the open water to the south of Storfjorden (Fig. 1), while the ROMS ice cover remains north of the southern tip of Spitsbergen (Fig. 5). This ice-free area is kept open in the model by warmer water advected in by the Norwegian Atlantic Current, and surface temperatures between Spitsbergen and Bjørnøya are commonly $3-4{ }^{\circ} \mathrm{C}$ even during the winter. The discrepancy is likely caused by unrealistically strong Atlantic inflow to the Barents Sea in the intermediate-scale simulation used as forcing on the boundaries (Budgell, 2005).

The analytical polynya modelling study of Skogseth and others (2004) suggests that the 1999/2000 winter had the highest accumulated ice production in the 1998-2001 period. This was associated with an estimated heat flux of $206 \mathrm{~W} \mathrm{~m}^{-2}$ during the winter, and the mean polynya width was found to be $57 \mathrm{~km}$. The polynya is defined to include open water, frazil/grease ice, and 'thin ice' areas, and is limited by pack ice and fast ice. Pack ice and fast ice are easily distinguishable from the polynya using satellite SAR images: 'They present structures of ice floes and show only moderate or no changes in sequential images 3 days apart' (Haarpaintner and others, 2001). The major polynya events detected by Skogseth and others (2004) in this way appeared in the period 20 January-15 March. Of the total ice production in Storfjorden this winter, frazil ice growth in open water accounted for $67 \%, 11 \%$ was thin-ice growth and $22 \%$ was growth of fast and pack ice. The mean polynya length alongshore (perpendicular to the ice drift) is $48 \mathrm{~km}$.

It is not straightforward to compare the analytical modelling validated using SAR images and our model results, as the size of our polynyas will depend on the criterion used. Our suggestion is to use a value of the 'mean ice thickness', i.e. the product of the ice thickness and the normalized concentration (0-1.0 values). Here we define a polynya to have a mean ice thickness $<0.3 \mathrm{~m}$. Accordingly the polynya width on 6 February is $20 \mathrm{~km}$, similar in size to the monthly mean shown in Figure 5. If we use $0.2 \mathrm{~m}$ as the maximum polynya mean ice thickness, the polynya width on 6 February decreases to $18 \mathrm{~km}$, but the monthly mean decreases to about $10 \mathrm{~km}$. The mean size will depend on this choice, but the temporal variation will be similar. The polynya criterion corresponds in our case to an ice concentration of $60-70 \%$ (Fig. 2).

Previously other polynya definitions have been used. Polynya size estimates based on remote sensing typically use ice concentration, and Massom and others (1998) used values below $75 \%$ as the polynya criterion. Recently Marsland and others (2004) suggested using a rate of freezing above $1 \mathrm{~m} \mathrm{month}^{-1}$, in addition to a $<70 \%$ sea-ice concentration criterion, to discriminate between the polynya and the surrounding pack ice. An ice concentration of $40-60 \%$ is termed 'open pack ice' and is generally not an indication of a polynya (WMO, 1970). Another polynya criterion in addition to the ice concentration seems necessary, but we suggest that the ice thickness is a more general criterion than freezing rate for two reasons: (i) in situ field measurements, as well as remote sensing (from laser altimetry or electromagnetic induction), also measure
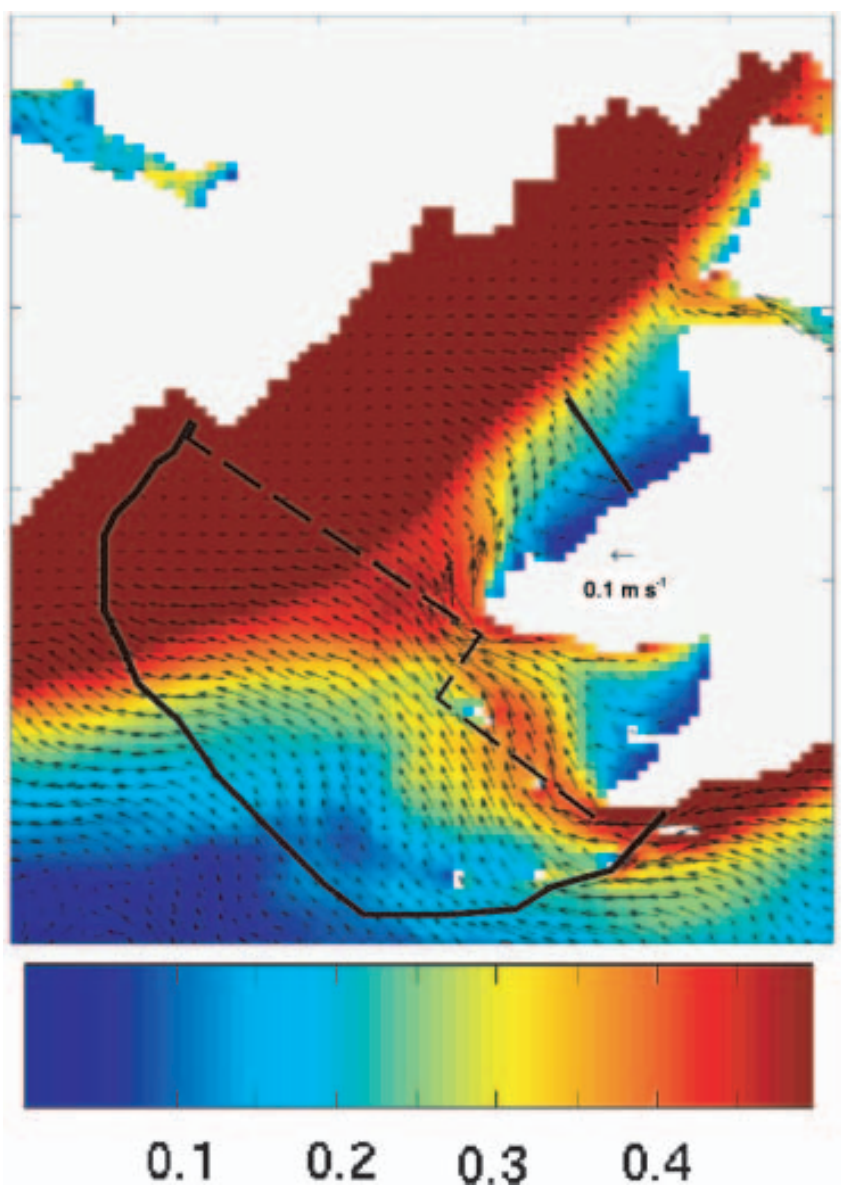

Fig. 5. Mean ice thickness calculated by the ROMS model during February in Storfjorden. This is the product of the model ice thickness $(\mathrm{m})$ and the normalized concentration averaged over the full month. The thick straight line indicates a polynya width of $20 \mathrm{~km}$, and the thick curved line denotes the outer extent of the Storfjorden basin. The mean polynya width (Fig. 6) was calculated north of the thin dashed line.

thickness, and a polynya size estimate can then be produced through these methods as well. (ii) A freezing rate does not work for sensible-heat polynyas, like the Weddell Polynya, Antarctica, where the heat flux to the atmosphere comes from upwelling water with temperatures above freezing.

A $0.3 \mathrm{~m}$ mean ice-thickness limit of the polynya extent matches the conventional limit between young ice (thinner than $0.3 \mathrm{~m}$ ) and first-year ice (WMO, 1970). This polynya criterion agrees with the results of Björnsson and others (2001), although they used the horizontal gradient in ice concentration, thickness and ice production to define the polynya edge. In our results, these gradients are not so distinct, but as we apply natural forcing and a realistic coastline, such idealized structures are not to be expected. We note that model cells with $<0.3$ m mean ice thickness do not always define a polynya; the cells also have to be surrounded by a larger mean thickness or a coastline. In our polynya area calculation we thus excluded an area in the southern part of Storfjorden in which there was a gradual transition to open water (Fig. 5).

There are three different polynya areas in ROMS visible in Figure 5. The main one is in the centre of the west coast of Edgeøya. There is also one along the southern peninsula of Edgeøya, and the smallest polynya appears west of 


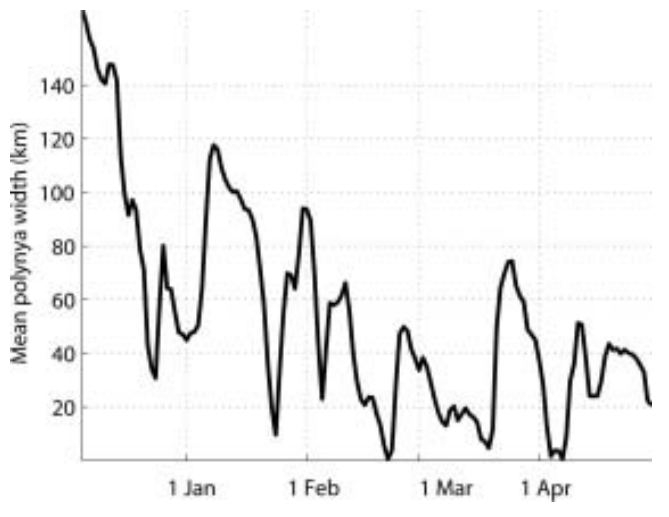

Fig. 6. Daily total polynya area in Storfjorden during winter 2000 divided by a mean length of $48 \mathrm{~km}$. The polynya area is found by multiplying by $48 \mathrm{~km}$. The area covered is shown in Figure 5 .

Barentsøya to the north (Fig. 1). Using our polynya criterion, we calculate the polynya area each day from 1 December to 30 April, and obtain a mean value of $2145 \mathrm{~km}^{2}$. This is $16.5 \%$ of the total area of Storfjorden (indicated in Fig. 5).

The mean polynya width is shown in Figure 6 . The average polynya width for December-April is $44.7 \mathrm{~km}$. This was calculated from the polynya area at any given day divided by a constant polynya length of $48 \mathrm{~km}$. This polynya length, i.e. the distance alongshore and perpendicular to the polynya width, is the value used by Skogseth and others (2004) and is also the length of our central polynya. We mainly discuss the mean polynya width here, as it is easier to remember and is equal to the mean polynya area when multiplied by $48 \mathrm{~km}\left(=2145 \mathrm{~km}^{2}\right)$. We also obtain large contributions from areas other than the central polynya. The largest polynya widths occur during December and January in Figure 6, but this is more a general freeze-up, i.e. the first ice formation this winter, and not proper polynya formation. The February-April mean modelled polynya width for all of Storfjorden is $34.3 \mathrm{~km}$, a value more representative of the 'mean' polynya width, or area.

Our model polynya width is thus lower than the estimated mean of $57 \mathrm{~km}$ from the analytical model. Our maximum daily polynya width from the main contributing central polynya off Edgeøya is $24 \mathrm{~km}$ (26 February). On some days (e.g. 24 March in Fig. 6), the polynya appears to be wider, but on such days the polynya length is much greater than the constant value of $48 \mathrm{~km}$.

On 6 February a SAR image indicates a polynya of $125 \mathrm{~km}$ width covering almost the full length of Storfjorden (Skogseth and others, 2004). This area is similar to the area in ROMS with an ice cover thinner than $0.6 \mathrm{~m}$ (see Fig. 3). As noted above, on this day the modelled polynya is $20 \mathrm{~km}$ wide, but with a very different orientation. The model polynya formed perpendicular to the axis of the fjord on the lee side of Edgeøya, while the SAR image indicates that the polynya forms along the axis of Storfjorden. As the ice cover responds directly to the surface winds, the coarse-resolution NCEP forcing is a likely candidate to explain the qualitative difference in the polynya orientation.

The steady-state polynya width is determined by a balance between ice growth and advection, and may be defined as in the analytical models (Björnsson and others, 2001):

$$
L_{\mathrm{p}}=\frac{H U}{F}=\frac{H U \rho_{\mathrm{i}} L}{Q} .
$$

Here $H$ is the ice export thickness from the polynya, $U$ is the ice speed and $F$ is the average ice production rate within the polynya. $F$ is again dependent on the mean heat flux $Q$, the ice density $\rho_{\mathrm{i}}=920 \mathrm{~kg} \mathrm{~m}^{-3}$, and the latent heat of freezing, $L=2.57 \times 10^{5} \mathrm{~J} \mathrm{~kg}^{-1}$. Therefore $L_{\mathrm{p}}$ decreases with increasing $Q$, if the other parameters are constant. Our polynya edge ice-thickness definition makes $H=$ $0.3 \mathrm{~m}$ (as the ice concentration is 1 in the analytical model), and $U$ may be estimated from the monthly mean ice export in Figure 5 as $0.06 \mathrm{~m} \mathrm{~s}^{-1}$. A mean heat flux of $200 \mathrm{~W} \mathrm{~m}^{-2}$ gives $L_{\mathrm{p}}=21.4 \mathrm{~km}$, decreasing to $14.3 \mathrm{~km}$ with $Q=300 \mathrm{~W} \mathrm{~m}^{-2}$. Therefore there is a general consistency between the earlier analytical models and our fine-scale ROMS application.

An ice concentration of $30-50 \%$ and an ice thickness of $0.1-0.2 \mathrm{~m}$ within the polynya is qualitatively quite representative for the in situ sampling performed close to Edgeøya during March 2004. Grease-ice and solid-ice floes of 0.05-0.4 $\mathrm{m}$ were observed to be interspersed with each other at the polynya edge (Smedsrud and Skogseth, 2006). Again it is not so straightforward to validate the results, as the grease-ice thickness may vary over the full range within a distance of $25 \mathrm{~m}$, and the field survey did not reach the polynya interior.

The growth of frazil ice within the model cells' openwater fractions is parameterized and tuned to fit the Arctic Ocean ice cover (Mellor and Kantha, 1989). This parameterization assumes that all of the surface heat flux is converted instantly into the latent heat of freezing of frazil ice crystals, and that there is no supercooling present within the surface grease ice. This is consistent with field measurements that indicated no present supercooling (Smedsrud and Skogseth, 2006), and laboratory experiments showing maximum supercooling on the level of $0.02^{\circ} \mathrm{C}$ (Smedsrud, 2001).

One of the more complex parts of the sea-ice model calculations is determining how much of the ice formation in open water contributes to changing the ice thickness, and how much contributes to changing the ice concentration. We used an empirical factor $\Phi=4.0$ in the equation for changes in sea-ice area following Mellor and Kantha (1989):

$$
h_{\mathrm{l}}\left(\frac{\partial A}{\partial t}+\frac{\partial A U_{\mathrm{Ii}}}{\partial x_{i}}\right)=\frac{\rho_{\mathrm{W}}}{\rho_{\mathrm{i}}}\left[\Phi(1-A) W_{\mathrm{AO}}+(1-A) W_{\mathrm{FR}}\right] \text {. }
$$

Here $h_{\mathrm{l}}$ is the ice thickness, $A$ the ice concentration, $U_{\mathrm{l} i}$ the ice speed in the $x_{i}$ direction and $\rho_{\mathrm{w}}$ a mean water density. For freezing conditions, $W_{\mathrm{AO}}$ is the (positive) volume flux from open water to ice, and $W_{\mathrm{FR}}$ is the frazil ice flux. For freezing conditions, $\Phi=4.0$ was found to represent average Arctic sea-ice concentrations (Mellor and Kantha, 1989), but in situ sea-ice concentration and thickness measurements are required to validate this value within a latent-heat polynya. The data from March 2004 (Smedsrud and Skogseth, 2006) may serve to validate this parameter after applying a more detailed, and realistic, surface wind forcing. Better wind forcing will require a oneway coupling to detailed atmospheric model results, and is work in progress.

Future development of the ice code should consider incorporating a separate grease-ice class to capture the 'greasiness', i.e. changed viscosity of the grease-ice layer, and describe a more gradual change in properties from open water to solid sea ice. Grease-ice thickness and concentration measurements from the interior of a polynya would be required to build such a parameter. 


\section{CONCLUSION}

The ROMS model was applied to the Storfjorden area, modelling ice growth and decay in the period August 1999July 2000 at $2 \mathrm{~km}$ resolution. The model performs well, reproducing the seasonal growth and decay of the ice cover, and areas with an ice cover thicker than $1 \mathrm{~m}$ along the western shores of Storfjorden resembling fast ice. Sea-ice concentrations in Storfjorden are realistic, but are too low outside the fjord in the Barents Sea.

ROMS forms a polynya in Storfjorden by advecting sea ice away from Edgeøya, and gradually growing thicker ice with a higher concentration away from the shore. The ice concentration and thickness increase steadily away from the open water close to shore.

The periods and location of polynya formation, as interpreted from satellite SAR images during January-March 2000, are well reproduced by the model. We suggest that a mean ice thickness, i.e. a product of the sea-ice concentration and thickness in a model cell of $<0.3 \mathrm{~m}$, is a suitable criterion to define a polynya.

The monthly mean polynya width estimates are comparable with results from general analytical models, but smaller than the SAR images indicate. The typical size of a central polynya is roughly $50 \mathrm{~km} \times 20 \mathrm{~km}$, but other areas add to this, making the 2000 winter mean polynya area roughly $50 \mathrm{~km} \times 33 \mathrm{~km}\left(1700 \mathrm{~km}^{2}\right.$, or $13 \%$ of the total Storfjorden area). This excludes the general freeze-up of the fjord during December and January. The mean polynya area estimate is $60 \%$ of the size obtained from SAR-based modelling. A possible candidate for this discrepancy is the coarse resolution of the atmospheric forcing, but the SAR images do not carry information about sea-ice thickness.

Our results document that the sea-ice model produces realistic results when applied on a detailed grid, and that further improvements in the modelling of polynyas will require new in situ measurements of both solid-ice and grease-ice properties from the polynya interior.

\section{ACKNOWLEDGEMENTS}

This work was conducted as a part of the Polar Ocean Climate Processes project (PROCLIM), funded by grant 155923/700 from the Research Council of Norway under contract with the Bjerknes Centre for Climate Research and the Geophysical Institute of the University of Bergen. This work has received support from the Research Council of Norway (Programme for supercomputing) through a grant of computing time. We are grateful to two anonymous reviewers for many important improvements and clarifications. This is publication No. A 121 from the Bjerknes Centre for Climate Research.

\section{REFERENCES}

Björnsson, H., A.J. Willmott, L.A. Mysak and M.A. Morales Maqueda. 2001. Polynyas in a high-resolution dynamicthermodynamic sea ice model and their parameterization using flux models. Tellus, 53A(2), 245-265.

Budgell, W.P. 2005. Numerical simulation of ice-ocean variability in the Barents Sea region towards dynamical downscaling. Ocean Dyn., 55(3-4), 370-387.
Cavalieri, D.J. and S. Martin. 1994. The contribution of Alaskan, Siberian, and Canadian coastal polynyas to the cold halocline layer of the Arctic Ocean. J. Geophys. Res., 99(C9), 18,34318,362 .

Dokken, S.T., P. Winsor, T. Markus, J. Askne and G. Björk. 2002. ERS SAR characterization of coastal polynyas in the Arctic and comparison with SSM/I and numerical model investigations. Remote Sens. Environ., 80(2), 321-335.

Engedahl, H. 1995. Use of the flow relaxation scheme in a threedimensional baroclinic ocean model with realistic topography. Tellus, 47A(3), 365-382.

Haarpaintner, J., J. Gascard and P.M. Haugan. 2001. Ice production and brine formation in Storfjorden, Svalbard. J. Geophys. Res., 106(C7), 14,001-14,014.

Häkkinen, S. and G.L. Mellor. 1992. Modeling the seasonal variability of a coupled Arctic ice-ocean system. J. Geophys. Res., 97(C12), 20,285-20,304.

Hunke, E.C. 2001. Viscous-plastic sea ice dynamics with the EVP model: linearization issues. J. Comput. Phys., 170(1), 18-38.

Hunke, E.C. and J.K. Dukowicz. 1997. An elastic-viscous-plastic model for sea ice dynamics. J. Phys. Oceanogr., 27(9), 1849-1867.

Kalnay, E. and 21 others. 1996. The NCEP/NCAR 40-year reanalysis project. Bull. Am. Meteorol. Soc., 77(3), 437-471.

Marsland, S.J., N.L. Bindoff, G.D. Williams and W.F. Budd. 2004. Modeling water mass formation in the Mertz Glacier Polynya and Adélie Depression, East Antarctica. J. Geophys. Res., 109(C11), C11003. (10.1029/2004JC002441.)

Massom, R.A., P.T. Harris, K.J. Michael and M.J. Potter. 1998. The distribution and formative processes of latent-heat polynyas in East Antarctica. Ann. Glaciol., 27, 420-426.

Mellor, G.L. and L. Kantha. 1989. An ice-ocean coupled model. J. Geophys. Res., 94(C8), 10,937-10,954.

Mellor, G.L. and T. Yamada. 1982. Development of a turbulent closure model for geophysical fluid problems. Rev. Geophys. Space Phys., 20(4), 851-875.

Morales Maqueda, M.A., A.J. Willmott and N.R.T. Biggs. 2004. Polynya dynamics: a review of observations and modeling. Rev. Geophys., 42(1), RG1004. (10.1029/2002RG000116.)

Pease, C.H. 1987. The size of wind-driven coastal polynyas. J. Geophys. Res., 92(C7), 7049-7059.

Shchepetkin, A.F. and J.C. McWilliams. 2005. The regional oceanic modeling system (ROMS): a split-explicit, free-surface, topography-following-coordinate oceanic model. Ocean Model., 9(4), 347-404.

Skogseth, R., P.M. Haugan and J. Haarpaintner. 2004. Ice and brine production in Storfjorden from four winters of satellite and in situ observations and modeling. J. Geophys. Res., 109(C10), C10008. (10.1029/2004JC002384.)

Skogseth, R., P.M. Haugan and M. Jakobsson. 2005. Watermass transformations in Storfjorden. Continental Shelf Res., 25(5-6), 667-695.

Smedsrud, L.H. 2001. Frazil-ice entrainment of sediment: largetank laboratory experiments. J. Glaciol., 47(158), 461-471.

Smedsrud, L.H. and R. Skogseth. 2006. Field measurements of Arctic grease ice properties and processes. Cold Reg. Sci. Technol., 44(3), 171-183.

Warner, J.C., C.R. Sherwood, H.G. Arango and R.P. Signell. 2005. Performance of four turbulence closure models implemented using a generic length scale method. Ocean Model., 8(1-2), 81-113.

Wessel, P. and W.H.F. Smith. 1996. A global self-consistent, hierarchical, high-resolution shoreline database. J. Geophys. Res., 101(B4), 8741-8743.

Winsor, P. and G. Björk. 2000. Polynya activity in the Arctic Ocean from 1958 to 1997. J. Geophys. Res., 105(C4), 8789-8803.

World Meteorological Organization (WMO). 1970. WMO sea-ice nomenclature. Geneva, World Meteorological Organization. (WMO-No. 259,TP.145 ed.) 